\title{
Pengaruh Karakteristik Organisasi, Kesesuaian Kompensasi, Sistem Pengendalian Internal dan Budaya Etis terhadap Fraud Pengadaan Barang/Jasa
}

\author{
Nurlaili Fithriani ${ }^{1}$ \\ Fakultas Ekonomi dan Bisnis \\ Universitas Mataram, Indonesia \\ Email: nurlailifithriani@gmail.com
}

\author{
Endang Pituringsih ${ }^{2}$ \\ Fakultas Ekonomi dan Bisnis \\ Universitas Mataram, Indonesia
}

\author{
M. Firmansyah ${ }^{3}$ \\ Fakultas Ekonomi dan Bisnis \\ Universitas Mataram, Indonesia
}

\begin{abstract}
ABSTRAK
Tujuan penelitian iniuntuk mengujiapakah variabel karakteristik TPK, kesesuaian kompensasi, sistem pengendalian internal, dan budaya etis memiliki pengaruh terhadap fraud pengadaan barang/jasa. Penelitian dilakukan pada Instansi Pemerinta Desa di Kabupaten Lombok Tengah. Penelitian ini menggunakan pendekatan kuantitatif dengan menggunakan data primer yang dikumpulkan dengan metode survey melalui pengiriman kuesioner kepada responden. Teknik sampling yang digunakan adalah Claster Random Sampling, sehingga diperoleh 195 orang di 65 desa di Kabupaten Lombok Tengah. Hasil penelitian menunjukkan bahwa karakteristik Tim Pengelola Kegiatan (TPK) dan budaya etis berpengaruh negative signifikan terhadap fraud pengadaan barang/jasa, kesesuaian kompensasi berpengaruh positif signifikan terhadap fraud pengadaan barang/jasa, sedangkan sistem pengendalian internal tidak berpengaruh terhadap fraud pengadaan barang/jasa.
\end{abstract}

Kata Kunci: Karakteristik Organisasi; Kesesuaian Kompensasi; Sistem Pengendalian Internal; Budaya Etis; Fraud Pengadaan Barang/Jasa.

\section{Influence of Organizational Characteristics, Compatibility} Compensation, Internal Control Systems and Ethical Culture of Goods / Services Procurement Fraud

\section{ABSTRACT}

The purpose of this study is to examine whether the TPK characteristic variables, the suitability of compensation, internal control systems, and ethical culture have an influence on fraud procurement of goods / services. The study was conducted at the Village Government Agency in Central Lombok Regency. This research uses a quantitative approach using primary data collected by survey method through sending questionnaires to respondents. The sampling technique used was Claster Random Sampling, so that 195 people were obtained in 65 villages in Central Lombok Regency. The results showed that the characteristics of the Activity Management Team (TPK) and ethical culture had a significant negative effect on goods / services procurement fraud, compensation suitability had a significant positive effect on goods / services procurement fraud, while the internal control system had no effect on goods / services procurement fraud.

Keywords: Organizational Characteristics; Suitability of compensation Internal Control System; Ethical Culture; Goods / Services Procurement Fraud.

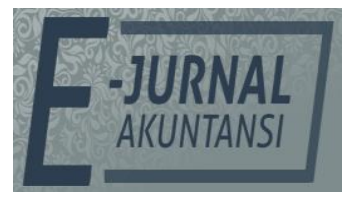

E-JA

e-Jurnal Akuntansi e-ISSN 2302-8556

Vol. 30 No. 7

Denpasar, Juli 2020 Hal.1843-1856

Artikel Masuk: 19 Juni 2020

Tanggal Diterima: 10 Juli 2020

The Article is Available in: https://ojs.unud.ac.id/index.php/Akuntansi/index 


\section{PENDAHULUAN}

Berdasarkan UU Nomor 6 Tahun 2014 Tentang Desa mendefinisikan desa adalah kesatuan masyarakat hukum yang memiliki batas wilayah yang berwenang untuk mengatur dan mengurus urusan pemerintahan, kepentingan masyarakat setempat berdasarkan prakarsa masyarakat, hak asal usul, dan/atau hak tradisional yang diakui dan dihormati dalam sistem pemerintahan Negara Kesatuan Republik Indonesia.Selain itu, dijelaskan unsur pemerintahan dalam kesatuan desa disebut dengan pemerintah desa, dimana pemerintah desa dijabat oleh seorang kepala desa yang dibantu oleh beberapa staf dan perangkat desa.

UU Nomor 6 Tahun 2014 beserta peraturan pelaksanaannya telah mengamanatkan pemerintah desa untuk lebih mandiri dalam mengelola pemerintahan dan berbagai sumber daya alam yang dimiliki, termasuk di dalamnya pengelolaan keuangan dan kekayaan milik desa. Dalam pengelolaan dana desa, Kepala Desa sebagai penyelenggara pemerintahan desa bertanggungjawab penuh terhadap pengelolaan dana desa. Salah satu bentuk pengelolaan dana desa adalah Belanja Desa, yakni dengan Pengadaan Barang/Jasa (PBJ) yang diharapkan dapat memperlancar penyelenggaraan pembangunan yang dilaksanakan oleh Pemerintahan Desa.Untuk memenuhi unsur pemerintahan yang baik, maka pengelolaan PBJ di desa perlu diatur dengan suatu peraturan perundang-undangan. Sebagai pedoman untuk penyusunan tata cara pelaksanaan pengadaan barang/jasa di desa yang dibiayai dalam APBDes, maka disusunlah Peraturan Kepala Lembaga Kebijakan Pengadaan Barang/Jasa Pemerintah (LKPP) Nomor 13 Tahun 2013 tentang Pedoman Tata Cara Pengadaan Barang/Jasa Di Desa, sebagaimana diubah dengan Peraturan Kepala LKPP Nomor 22 Tahun 2015 yang pada dasarnya diberlakukan dengan maksud agar menjadikan pedoman bagi Bupati/Walikota untuk menyusun Peraturan Bupati/Walikota berikut petunjuk pelaksanaannya mengenai Tata Cara Pengadaan Barang/Jasa di Desa dengan memperhatikan tata nilai PBJ yang memuat prinsip dan etika PBJ. Namun dalam pelaksanaannya seringkali dijumpai berbagai penyimpangan dalam proses pengadaan barang/jasa, bahkan dilansir oleh detik news (2018) bahwa sektor pengadaan barang dan jasa merupakan wilayah yang rentan terjadi tindak korupsi. Salah satu kabupaten yang terindikasi terjadinya tindakan kecurangan (fraud) dalam pengadaan barang dan jasa desa yaitu di Kabupaten Lombok Tengah.

Berdasarkan Laporan Hasil Pemeriksaan (LHP) Badan Pemeriksa Keuangan (BPK) 2018 di NTB, Kepala Pelaksana BPK NTB, Hery Purwanto mengungkapkan, dari keseluruhan hasil pemeriksaan yang tidak layak atau tidak sah dari penggunaan anggaran desa-desa besarnya mencapai Rp 1,7 miliar atas pengelolaan keuangan desa tahun 2017 hingga Semester I Tahun Anggaran 2018. Hery menyoroti jika di Lombok Tengah banyak desa yang memberikan Laporan Keterangan Pertanggungjawaban (LKPJ) yang tidak sesuai, dalam hal ini ditemukan sebanyak Rp280 juta, uang negara tidak dapat dipertanggung jawabkan (Gatra.com, 2018). Penyalahgunaan uang Negara tersebut dilakukan dalam kasus pengadaan barang dan jasa seperti pengadaan meuble dimana harganya Rp 10 juta akan tetapi dalam laporan yang tertuang pada kwitansi sebesar Rp 15 juta. Selain itu juga terjadi dalam pengerjaan fisik seperti upah tukang per hari, dimana pada nota pembayaran tertuang sebesar Rp 200.000, 
setelah didalami dengan seara langsung bertemu dengan pekerja yang bersangkutan terdapat pengakuan diminta tanda tangan tidak sesuai fakta (Gatra.com, 2018).

Masalah pengadaan tidak pernah terlepas dari sorotan berbagai kalangan walaupun sudah terdapat peraturan yang mengatur pengadaan tersebut. Hasil penelitian Clinard \& Cressey, 1954 menemukan fakta apa yang disebut dengan teori fraud triangle, yaitu setiap terjadinya kecurangan dipengaruhi oleh tiga hal diantaranya: (1) adanya tekanan/dorongan (pressure/motivasion), (2) rasionalisasi/pembenaran (rationalization), (3) adanya peluang/kesempatan (opportunity).Tekanan (pressure) adalah motivasi dari individu pegawai untuk bertindak fraud dikarenakan adanya tekanan baik keuangan dan non keuangan dari pribadi maupun tekanan dari organisasi. Panggabean (2016) mengemukakan bahwa pegawai yang mengalami ketidak puasan dengan gaji yang diperoleh cenderung mencari penghasilan lain, yang dalam hal ini mencari penghasilan dain dengan melakukan kecurangan. Opportunity adalah peluang yang memungkinkan terjadinya fraud disebabkan karena control internal suatu organisasi yang lemah, kurangnya pengawasan, dan/atau penyalah gunaan wewenang. Sistem pengendalian internal pemerintah yang tidak dijalankan memberikan peluang bagi pihak tertentu di pemerintahan untuk melakukan kecurangan. Rasionalisasi (rationalization) adalah pertimbangan perilaku kecurangan sebagai konsekuensi dari kesenjangan integritas pribadi pegawai atas penalaran moral yang lain.

Penelitian yang telah dilakukan oleh Arifianti, et al., (2016) menunjukkan bahwa karakteristik pokja ULP/ pejabat pengadaan berpengaruh negatif signifikan terhadap fraud pengadaan barang/jasa. Penelitian Hidayati \& Mulyadi (2017) menunjukkan bahwa kualitas panitia pengadaan berpengaruh secara signifikan dan negatif terhadap fraud pengadaan barang/jasa. Hasil berbeda diperoleh dari penelitian Heljapri, (2015) yang menyatakan bahwa kualitas panitia pengadaan barang/jasa tidak berpengaruh terhadap fraud pengadaan barang/jasa.

Penelitian yang telah dilakukan oleh Penelitia Aji (2013) dan Panggabean (2016) menunjukkan bahwa terdapat pengaruh yang negatif dan signifikan dalam penilaian penghasilan panitia pengadaan barang/jasa pemerintah. Penelitian Sanuari (2014) menunjukkan bahwa kesesuaian kompensasi berpengaruh negatif dan signifikan terhadap fraud. Hasil berbeda diperoleh dari penelitian yang dilakukan oleh Arifianti (2015) yang menunjukkan bahwa kesesuaian kompensasi tidak berpengaruh terhadap fraud pengadaan barang/jasa.

Penelitian yang telah dilakukan oleh Arifianti (2015) dan Nisa Nurharjanti (2017) menunjukkan bahwa sistem pengendalian intern berpengaruh terhadap fraud pengadaan barang/jasa. Penelitian Zulaikha \& Hadiprajitno (2016) hasil penelitian menunjukkan bahwa fraud pengadaan barang dan jasa pemerintah dipengaruhi secara signifikan oleh adanya kelemahan dalam sistem pengadaan. Hasil berbeda diperoleh dari penelitian Rahmi \& Helmayunita (2019) menunjukkan bahwa sistem pengendalian internal tidak berpengaruh pada kecenderungan kecurangan akuntansi. Penelitian Akbar, et al., (2012) dimana sistem pengendalian internal sudah berjalan dengan baik dan 
selayaknya, akan tetapi masih terdapat salah saji atau salah material yang ditimbulkan karena moral seseorang individu untuk berbuat curang dan seakan sistem yang berjalan salah.

Penelitian yang telah dilakukan oleh Aji (2013) menunjukkan bahwa etika pengadaan berpengaruh negatif dan signifikan terhadap penyimpangan dalam pengadaan barang dan jasa pemerintah. Penelitian Panggabean (2016) menunjukkan bahwa secara serempak budaya etis organisasi berpengaruh signifikan terhadap fraud di lingkungan instansi pemerintah, namun secara parsial budaya etis organisasi berpengaruh negatif signifikan terhaadap fraud di lingkungan instansi pemerintah. Hasil berbeda diperoleh dari penelitian Najahningrum (2013) menunjukkan bahwa tidak terdapat pengaruh antara budaya etis organisasi dengan fraud di sektor pemerintahan.

Hasil penelitian yang berbeda menunjukkan adanya ketidak konsistenan antara penelitian-penelitian sebelumnya sehingga belum dapat menegaskan bahwa teori-teori karakteristik TPK, kesesuaian kompensasi, sistem pengendalian internal, dan budaya etis organisasi berpengaruh terhadap fraud khususnya dalam pengadaan barang/jasa. Hal ini memotivasi peneliti untuk melakukan penelitian dengan judul "Pengaruh Karakteristik Tim Pengelola Kegiatan (TPK), Kesesuaian Kompensasi, Sistem Pengendalian Internal, dan Budaya Etis Organisasi Terhadap Fraud Pengadaan Barang/Jasa. Penelitian ini dilakukan pada Instansi Pemerintah Desa Di Kabupaten Lombok Tengah.

Jensen \& Meckling (1976) mendefinisikan hubungan keagenan sebagai suatu kontrak antara satu orang atau lebih yang bertindak sebagai prinsipal (pemilik) yang menunjuk orang lain sebagai agen (manajer) untuk melakukan jasa untuk kepentingan prinsipal termasuk mendelegasikan kekuasaan dalam pembuatan keputusan. Teori keagenan ini menyebabkan adanya akuntabilitas kinerja yang menunjukkan bahwa seberapa besar pertanggungjawaban antara agent dalam memberikan informasi kepada principal mengenai keberhasilan atau kegagalan suatu aktivitas pelaksanaan misi organisasi dalam perusahaan (Mardiasmo, 2018).

Fraud atau kecurangan adalah suatu tindakan yang disengaja oleh satu individu atau lebih dalam manajemen atau pihak yang bertanggungjawab atas tata kelola, karyawan, dan pihak ketiga yang melibatkan penggunaan tipu muslihat untuk memperoleh satu keuntungan secara tidak adil atau melanggar hukum (IAPI, 2013).

Cressey (1973) dalam Tuanakotta (2010) menyatakan bahwa ada tiga penyebab atau pemicu terjadinya fraud, yaitu: 1) Tekanan (Unshareable pressure/incentive) adalah motivasi dari individu karyawan untuk bertindak fraud dikarenakan adanya tekanan baik keuangan dan non keuangan dari pribadi maupun tekanan dari organisasi. 2) Kesempatan/peluang (Preceive Opportunity) adalah peluang terjadinya fraud akibat lemahnya atau tidak efektivenya Kontrol sehingga membuat peluang terjadinya fraud. 3) Rasionalisasi (Rationalization) adalah fraud terjadi karena kondisi nilai-nilai etika lokal yang mendorong/membolehkan terjadinya fraud.

Pengadaan barang/jasa yang dilakukan dengan menggunakan pihak ketiga proses pengadaannya harus melalui panitia atau pejabat pengadaan. Dalam Perpres 54 Tahun 2010 dijabarkan bahwa tugas PBJ dilaksanakan oleh 
ULP/pejabat pengadaan, sedangkan dalam PBJ didesa, tugas pengelolaan pengadaan PBJ desa dilaksanakan oleh Tim Pengelola Kegiatan (TPK), baik pengadaan secara swakelola maupun melalu penyedia barang/jasa. Tugas TPK dalam melaksanakan PBJ desa meliputi kegiatan persiapan, pelaksanaan, pengawasan, penyerahan, pelaporan dan pertanggungjawaban hasil pekerjaan.

Kompensasi adalah semua yang diterima karyawan yang bertujuan sebagai balas jasa atas apa yang telah ddikirjekan oleh kayawan tesebut (Handoko, 2010). Di dalam kepegawaian, hadiah yang berupa uang, merupakan kompensasi yang diberikan pegawai sebagai penghargaan dari pelayanan mereka terhadap pekerjaan. Menurut teori Wexley, Kenneth, N \& Yukl (2000) mengatakan bahwa suatu kompensasi yang tidak adil atau tidak memadai serta pekerjaan yang menjemukan dapat mendukung insiden-insiden pencurian oleh para pekerja, dalam hal ini adalah pencurian aset perusahaan atau organisasi tersebut.

Standar Profesioanal Akuntan Publik (SPAP) pengendalian intern didefinisikan sebagai sebuah sistem pengendalian intern yang meliputi organisasi serta semua metode dan ketentuan yang terkoordinasi yang dianut dalam suatu perusahaan untuk melindungi harta miliknya, mencek kecermatan dan keandalan data akuntansi, meningkatkan efisiensi usaha, mendorong ditaatinya kebijakan manajemen yang telah digariskan. Sistem pengendalian intern yang efektif dapat membantu menjaga asset, menjamin tersedianya laporan keuangan dan managerial yang akurat dan dapat dipercaya, meningkatkan kepatuhan terhadap ketentuan dan peraturan perundangundangan yang berlaku.

Budaya etis organisasi merupakan satu pola tingkah laku, kepercayaan yang telah menjadi suatu panutan bagi semua anggota organisasi, tingkah laku disini merupakan suatu tingkah laku yang dapat diterima oleh moral dan benar secara hukum (Panggabean 2016). Budaya etis organisasi dapat mencakup berbagai konsep seperti benar, salah, baik, buruk dan tanggung jawab yang dapat memepengaruhi seseorang dalam melakukan berbagai hal.Suatu budaya etis organisasi yang buruk akan mempengaruhi seseorang dalam melakukan tindak kecurangan dan sebalikny, apabila budaya etis organisasi tersebut semakin baik, maka akan semakin rendah tingkat terjadinya kecurangan.

Agency theory dan triangle fraud menjelaskan bahwa antara prinsipal dan agen senantiasa terjadi masalah keagenan dalam proses pengadaan barang/jasa, oleh karena itu kualitas panitia pengadaan atau dalam penelitian ini disebut dengan karakteristik TPK (Tim Pengelola Kegiatan) dalam melaksanakan proses pengadaan barang/jasa dan segala aktivitas serta keputusan yang dilakukannya akan sangat menentukan jalannya proses pengadaan. Penelitian yang telah dilakukan oleh Arifianti (2015) menunjukkan bahwa karakteristik pokja ULP/ pejabat pengadaan berpengaruh negatif signifikan terhadap fraud pengadaan barang/jasa. Hidayati \& Mulyadi (2017) menunjukkan bahwa kualitas panitia pengadaan berpengaruh secara signifikan dan negatif terhadap fraud pengadaan barang/jasa. Berbeda dengan penelitian yang dilakukan oleh Heljapri (2015) yang menyatakan bahwa kualitas panitia pengadaan barang/jasa tidak berpengaruh terhadap fraud pengadaan barang/jasa. 
Panitia pengadaan yang terbentuk akan menentukan baik buruknya suatu proses pengadaan barang/jasa. Segala aktivitas dan keputusan yang diambil oleh TPK pengadaan merupakan hal yang sangat krusial karena berhadapan langsung dengan berbagai muatan kepentingan dari berbagai subyek pengadaan barang/jasa lainnya. Untuk itu kemampuan dan profesionalisme personil TPK pengadaan merupakan hal yang perlu diperhatikan.

$\mathrm{H}_{1}$ : Karakteristik Tim Pengelola Kegiatan berpengaruh negatif terhadap fraud pengadaan barang/jasa.

Kompensasi merupakan komponen biaya yang dibayarkan oleh organisasi pada karyawan sebagai pengganti jasa yang telah mereka berikan (Ahriati et al., 2015). Kesesuaian kompensasi sangat berpengaruh terhadap perilaku pegawai atau karyawan, biasanya seseorang akan berperilaku tidak etis dan berlaku curang untuk memaksimalkan keuntungan untuk dirinya sendiri karena ketidak puasan atau kekecewaan dengan kompensasi yang mereka terima atas apa yag telah dikerjakan (Shintadevi, 2016). Pemberian kompensasi yang sesuai prosedur yang telah ditetapkan diharapkan dapat memberikan rasa keadilan bagi para pegawai dan mengurangi tingkat kecurangan (fraud). Penelitian yang telah dilakukan oleh Aji (2013) dan Panggabean (2016) menunjukkan bahwa terdapat pengaruh yang negatif dan signifikan dalam penilaian penghasilan panitia pengadaan barang/jasa pemerintah. Penelitian Sanuari (2014) menunjukkan bahwa kesesuaian kompensasi berpengaruh negatif dan signifikan terhadap fraud. Berbeda dengan penelitian yang dilakukan oleh Arifianti (2015) yang menunjukkan bahwa kesesuaian kompensasi tidak berpengaruh terhadap fraud pengadaan barang/jasa.

Berdasarkan kajian teori, peneliti dapat menyimpulkan bahwa dengan pemberian kompensasi yang sesuai dan layak kepada pegawai dapat meminimalisir terjadinya fraud dalam proses pengadaan barang/jasa, namun sebaliknya apabila pemberian kompensasi tidak sesuai dengan semestinya maka akan terjadi peningkatan terjadinya fraud pengadaan barang/jasa.

$\mathrm{H}_{2}$ : Kesesuaian Kompensasi berpengaruh negatif terhadap fraud pengadaan barang/jasa.

Pengendalian internal dirancang untuk menyediakan keyakinan yang memadai berkaitan dengan tujuan beberapa kategori yaitu efektivitas dan efisiensi kegiatan, keandalan pelaporn keuangan dan ketaatan pada peraturan dan ketentuan yang berlaku (Karyono, 2013). Pengendalian internal yang efektif dapat melindungi dari pencurian, penggelapan, penyalahgunaan aktiva pada lokasi yang tidak tepat, serta dapat memberikan jaminan yang wajar terhadap informasi bisnis yang akurat demi keberhasilan perusahaan (Rahmi \& Helmayunita, 2019).

Penelitian terdahulu yang dilakukan oleh Arifianti (2015) dan Nisa Nurharjanti (2017) menunjukkan bahwa sistem pengendalian intern berpengaruh terhadap fraud pengadaan barang/jasa. Penelitian Zulaikha \& Hadiprajitno (2016) (2016) menunjukkan bahwa fraud pengadaan barang dan jasa pemerintah dipengaruhi secara signifikan oleh adanya kelemahan dalam sistem pengadaan. Berbeda dengan penelitian yang dilakukan oleh (Rahmi \& Helmayunita, 2019) menunjukkan bahwa sistem pengendalian internal tidak berpengaruh pada 
kecenderungan kecurangan akuntansi. Penelitian Akbar, et al., (2012) dimana sistem pengendalian internal sudah berjalan dengan baik dan selayaknya, akan tetapi masih terdapat salah saji atau salah material yang ditimbulkan karena moral seseorang individu untuk berbuat curang dan seakan sistem yang berjalan salah.

$\mathrm{H}_{3}$ : Sistem Pengendalian Internal berpengaruh negatif terhadap fraud pengadaan barang/jasa.

Budaya etis organisasi dapat diartikan sebagai pola atau sikap dan perilaku yang diharapkan dari setiap individu dalam organisasi secara keseluruhan yang akan membentuk budaya organisasi secara keseluruhan. Penelitian yang telah dilakukan oleh Aji (2013) dan menunjukkan bahwa etika pengadaan berpengaruh negatif dan signifikan terhadap penyimpangan dalam pengadaan barang dan jasa pemerintah. Penelitian Panggabean (2016) menunjukkan bahwa secara serempak budaya etis organisasi berpengaruh signifikan terhadap fraud di lingkungan instansi pemerintah, namun secara parsial budaya etis organisasi berpengaruh negatif signifikan terhaadap fraud di lingkungan instansi pemerintah. Artinya budaya etis organisasi yang buruk akan mempengaruhi seseorang dalam melakukan tindak kecurangan dan sebaliknya, apabila budaya etis organisasi tersebut semakin baik, maka akan semakin rendah tingkat terjadinya fraud. Berbeda dengan penelitian yang dilakukan oleh Najahningrum (2013) menunjukkan bahwa tidak terdapat pengaruh antara budaya etis organisasi dengan fraud di sektor pemerintahan.

$\mathrm{H}_{4}$ : Budaya Etis Organisasi berpengaruh negatif terhadap fraud pengadaan barang/jasa.

\section{METODE PENELITIAN}

Populasi adalah wilayah generalisasi yang terdiri atas: obyek/subyek yang mempunyai kualitas dan karakteristik tertentu yang ditetapkan oleh penelitian untuk dipelajari dan kemudian ditarik kesimpulannya (Sugiyono, 2015). Populasi dalam penelitian ini yaitu Tim Pengelola Kegiatan (TPK) sebanyak 381 orang yang terdiri dari ketua yang berasal dari unsur Perangkat Desa (Kepala Urusan/Kaur), sekretaris dan anggota yang berasal dari unsur LKMD di 127 Instansi Pemerintah Desa di Kabupaten Lombok Tengah.

Sampel adalah bagian dari jumlah dan karakteristik yang dimiliki oleh populasi tersebut (Sugiyono, 2015). Teknik atau pengambilan sampel yang digunakan dalam penelitian ini adalah Claster Random Sampling. Peneliti menggunakan teknik ini disebabkan oleh populasi desa di Kabupaten Lombok Tengah yang terdiri dari klaster-klaster desa. Kemudian berdasarkan random terhadap 127 desa, maka diperoleh sampel sebanyak 195 orang yang terdiri dari ketua, sekretaris, dan anggota di 65 desa di kabupaten Lombok Tengah.

Penelitian ini menggunakan pendekatan kuantitatif dengan menggunakan data primer yang dikumpulkan dengan metode survey melalui pengiriman kuesioner kepada responden. Pengiriman kuesioner dilakukan secara langsung kepada Tim Pengelola Kegiatan (TPK) yang bertugas dalam menjalankan pengadaan barang/jasa pada Instansi Pemerintah Desa di Kabupaten Lombok Tengah. Data dari kuesioner tersebut diolah menggunakan SPSS. Instrumen penelitian ini adalah kuesioner dengan menggunakan skala 
likert dengan lima alternatif jawaban, masing-masing diberi skor yaitu sangat setuju (SS), setuju (S), kurang setuju (KS), tidak setuju (TS), dan sangat tidak setuju (STS).

Analisis data yang digunakan adalah uji kualitas data yang terdiri dari uji validitas dan realiabilitas. Uji asumsi klasik yakni uji normalitas, uji multikolinearitas, dan uji heteroskedastisitas. Uji hipotesis menggunakan uji koefisien determinasi $\left(\mathrm{R}^{2}\right)$, uji regresi berganda, uji goodness of fit, uji $\mathrm{t}(\mathrm{t}-$ Test).

Persamaan regresi linear berganda pada penelitian ini dapat dirumuskan sebagai berikut:

$Y=\alpha+\beta 1 X 1+\beta 2 X 2+\beta 3 X 3+\beta 4 X 4+\varepsilon$

Dimana:

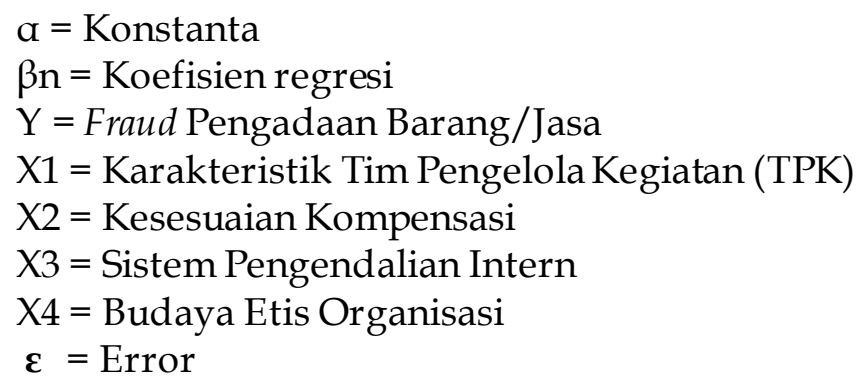

\section{HASIL DAN PEMBAHASAN}

Peneliti menyebarkan 195 kuesioner di 65 instansi pemerintah desa di Kabupaten Lombok Tengah. Kuesioner yang kembali sebanyak 140 (71,79\%). Sedangkan kuesioner yang tidak dapat diolah adalah $55(28,21 \%) .55$ kuesioner yang tidak kembalii dikarenakan kesibukan dan ketidakbersediaan responden untuk mengisi kuesioner. Jadi total kuesioner yang dapat diolah sebanyak 140 (71,79\%).

Tabel 1. Tingkat Pengumpulan Kuesioner

\begin{tabular}{lcc}
\hline Keterangan & Jumlah & Persentase \\
\hline $\begin{array}{l}\text { Total kuesioner } \\
\text { disebarkan }\end{array}$ & 195 & $100 \%$ \\
$\begin{array}{l}\text { Total kuesioner } \\
\text { terkumpul kembali }\end{array}$ & 140 & $71,79 \%$ \\
$\begin{array}{l}\text { Total kuesioner yang tidak } \\
\text { kembali }\end{array}$ & 55 & $28,21 \%$ \\
$\begin{array}{l}\text { Total kuesioner yang dapat } \\
\text { diolah }\end{array}$ & 140 & $71,79 \%$ \\
\hline
\end{tabular}

Sumber: Data Penelitian, 2020

Pengujian regresi linear berganda dapat dilakukan setelah model penelitian memenuhi syarat yaitu lolos dari pengujian asumsi klasik. Adapun syarat-syarat tersebut adalah normalitas, bebas multikolinieritas dan heteroskedastisitas.

Tabel 2. Hasil Uji Normalitas

\begin{tabular}{ll}
\hline Keterangan & Unstandardized Residual \\
\hline $\mathrm{N}$ & 140 \\
Kolmogorov-Smirnov Z & 0,737 \\
Asymp.Sig. & 0,648 \\
\hline
\end{tabular}

Sumber: Data Penelitian, 2020 
Berdasarkan Tabel 2, hasil uji Kolmogorov-Smirnov menunjukkan nilai Asymp. Sig. sebesar 0,648. Karena nilai Asymp. Sig. pada penelitian ini lebih besar dari 0,05 maka dapat dinyatakan bahwa residual terdistribusi seara normal.

Tabel 3. Hasil Uji Multikolinearitas

\begin{tabular}{lll}
\hline Variable & Tolerance & VIF \\
\hline Karakteristik TPK (X1) & 0,810 & 1,235 \\
Kesesuaian Kompensasi (X2) & 0,667 & 1,499 \\
Sistem Pengendalian Internal (X3) & 0,591 & 1,691 \\
Budaya Etis Organisasi (X4) & 0,651 & 1,536 \\
\hline
\end{tabular}

Sumber: Data Penelitian, 2020

Uji multikolinearitas dapat diketahui berdasarkan Variance Inflation Factor (VIF) atau nilai Tolerance. Jika nilai VIF lebih dari 10 (VIF > 10) dan angka Tolerance mendekati $<0,10$, maka terjadi masalah multikolinearitas. Sebaliknya, jika nilai VIF kurang dari 10 (VIF < 10), maka model regresi pada penelitian ini bebas dari masalah multikolinearitas. Berdasarkan Tabel 3, menunjukkan nilai tolerance variabel independen yaitu karakteristik Tim Pengelola Kegiatan (TPK), kesesuaian kompensasi, sistem pengendalian internal dan budaya etis organisasi memiliki nilai VIF lebih kecil dari 10 dan nilai tolerance tidak kurang dari 0,10, maka dapat disimpulkan bahwa model regresi bebas dari multikolinearitas.

Tabel 4. Hasil Uji Heteroskedastisitas

\begin{tabular}{lll}
\hline Variabel & T & Sig. \\
\hline Karakteristik TPK (X1) & 0,723 & 0,471 \\
Kesesuaian Kompensasi (X2) & $-0,537$ & 0,592 \\
Sistem Pengendalian Internal (X3) & $-0,198$ & 0,843 \\
Budaya Etis Organisasi (X4) & O,428 & 0,669 \\
\hline
\end{tabular}

Sumber: Data Penelitian, 2020

Data dikatakan terbebas dari heteroskedastisitas apabila secara statistik variabel bebas tidak berpengaruh signifikan terhadap variabel terikat Absolut Ut (AbsUt). Model regresi tidak mengandung heteroskedastisitas jika probabilitas signifikansinya diatas 0,05 (sig>0,05). Berdasarkan Tabel 4, menunjukkan nilai signifikansi lebih besar dari 0,05, dimana karakteristik Tim Pengelola Kegiatan (TPK) dengan nilai signifikansi sebesar 0,471, kesesuaian kompensasi dengan nilai signifikansi sebesar 0,592, sistem pengendalian internal dengan nilai signifikansi sebear 0,843 , dan budaya etis organisasi dengan nilai signifikansi sebesar 0,669. Maka dapat disimpulkan bahwa model regresi bebas dari heteroskedastisitas.

Tabel 5. Hasil Analisis Regresi Linear Berganda

\begin{tabular}{|c|c|c|c|c|c|}
\hline \multirow[t]{2}{*}{ Variabel } & \multicolumn{2}{|c|}{$\begin{array}{l}\text { Unstandardized } \\
\text { Coefficients }\end{array}$} & \multirow{2}{*}{$\begin{array}{l}\text { Standardized } \\
\text { Coefficients } \\
\text { Beta }\end{array}$} & \multirow[t]{2}{*}{$\mathrm{T}$} & \multirow[t]{2}{*}{ Sig. } \\
\hline & $\mathrm{B}$ & Std. Error & & & \\
\hline (Constan) & 27,883 & 3,767 & & 7,402 & 0,000 \\
\hline Karakteristik TPK $(\mathrm{X} 1)$ & $-0,367$ & 0,129 & $-0,251$ & $-2,856$ & 0,005 \\
\hline Kesesuaian Kompensasi (X2) & 0,648 & 0,205 & 0,306 & 3,152 & 0,002 \\
\hline $\begin{array}{l}\text { Sistem Pengendalian Internal } \\
\text { (X3) }\end{array}$ & $-0,164$ & 0,18 & $-0,094$ & $-0,911$ & 0,364 \\
\hline Budaya Etis Organisasi (X4) & $-0,335$ & 0,163 & $-0,201$ & $-2,052$ & 0,042 \\
\hline
\end{tabular}

a. Dependent Varibel: $Y$ 
Sumber: Data Penelitian, 2020

Berdasarkan Tabel 5, maka persamaan regresi linear berganda sebagai berikut:

$$
\mathrm{Y}=27,883-0,367 \mathrm{X} 1+0,648 \mathrm{X} 2-0,164 \mathrm{X} 3-0,335 \mathrm{X} 4
$$

Berdasarkan Tabel 5, dapat dilihat bahwa nilai konstanta (a) adalah 27,883, sedangkan koefisien regresi Karakteristik Tim Pengelola Kegiatan (TPK) (X1) sebesar -0,367, koefisien regresi kesesuaian kompensasi (X2) sebesar 0,648, koefisien regresi sistem pengendalian internal $(X 3)$ sebesar $-0,164$, dan koefisien regresi budaya etis organisasi $(X 4)$ sebesar $-0,335$.

Berdasarkan hasil analisis regresi linier berganda pada Uji $t$ terhadap hipotesis pertama $\left(\mathrm{H}_{1}\right)$ dapat dilihat bahwa karakteristik Tim Pengelola Kegiatan (TPK) berpengaruh terhadap fraud pengadaan barang/jasa dengan melihat taraf signifikansinya yaitu sebesar 0,005 kurang dari 0,05 dan Uji t menunjukkan nilai 2,856 yang berarti lebih besar dari t tabel 1,972. Hubungan yang ditunjukkan oleh koefisien regresi adalah negatif, artinya semakin baik karakteristik Tim Pengelola Kegiatan (TPK) maka fraud pengadaan barang/jasa akan semakin menurun sehingga $\mathrm{H}_{1}$ diterima. Penelitian ini didukung dengan hasil penelitian yang dilakukan oleh Arifianti, et al., (2016) yang menunjukkan bahwa karakteristik pokja ULP/ pejabat pengadaan berpengaruh negatif signifikan terhadap fraud pengadaan barang/jasa. Penelitian ini juga sejalan dengan pnelitian yang dilakukan oleh Hidayati \& Mulyadi (2017) yang menunjukkan bahwa kualitas panitia pengadaan berpengaruh secara signifikan dan negatif terhadap fraud pengadaan barang/jasa.

Agency theory dan triangle fraud menjelaskan dimana antara prinsipal dan agen senantiasa terjadi masalah keagenan dalam proses pengadaan barang/jasa, oleh karena itu kualitas panitia pengadaan atau dalam penelitian ini disebut dengan karakteristik Tim Pengelola Kegiatan (TPK) dalam melaksanakan proses pengadaan barang/jasa dan segala aktivitas serta keputusan yang dilakukannya akan sangat menentukan jalannya proses pengadaan. TPK yang terbentuk akan menentukan baik buruknya suatu proses pengadaan barang/jasa. Dalam penelitian ini, karakteristik Tim Pengelola Kegiatan (TPK) dilihat dari beberapa dimensi yaitu integritas, kompetensi, objektivitas, dan independensi. Hasil penelitian menunjukkan sebagian besar responden berpendapat bahwa kondisi Tim Pengelola Kegiatan (TPK) yang selalu menjunjung tinggi integritas, kompetensi, objektivitas, dan independensi akan menurunkan potensi terjadinya fraud.

Kompensasi adalah semua yang diterima karyawan yang bertujuan sebagai balas jasa atas apa yang telah dikerjakan oleh kayawan tesebut (Handoko, 2001:155). Berdasarkan hasil analisis regresi linier berganda pada Uji t terhadap hipotesis kedua $\left(\mathrm{H}_{2}\right)$ dapat dilihat bahwa kesesuaian kompensasi berpengaruh terhadap fraud pengadaan barang/jasa pada instansi pemerintah desa di kabupaten lombok tengah dengan melihat taraf signifikansinya yait $\mathrm{u}$ sebesar 0,002 kurang dari 0,05 dan Uji t menunjukkan nilai 3,152 yang berarti lebih besar dari t tabel 1,972. Hubungan yang ditunjukkan oleh koefisien regresi adalah positif, hal ini menunjukkan bahwa koefisien kesesuaian kompensasi memiliki hubungan yang searah dengan fraud pengadaan barang/jasa, sehingga 
mengandung arti jika kesesuaian kompensasi tinggi maka fraud pengadaan barang/jasa juga tinggi, maka $\mathrm{H}_{2}$ ditolak.

Hasil penelitian ini tidak sejalan dengan penelitian yang telah dilakukan oleh Aji (2013) dan Panggabean (2016) yang menunjukkan bahwa terdapat pengaruh yang negatif dan signifikan dalam penilaian penghasilan panitia pengadaan barang/jasa pemerintah, namun penelitian ini mendukung teori triangle fraud yaitu tekanan (Unshareable pressure/incentive). Tekanan (Unshareable pressure/incentive) adalah motivasi dari individu karyawan untuk bertindak fraud dikarenakan adanya tekanan baik keuangan dan non keuangan dari pribadi maupun tekanan dari organisasi. Penyebab terjadinya tekanan bisa disebabkan oleh tuntutan dan gaya hidup, dimana semakin tinggi imbalan yang diperoleh maka tuntutan dan gaya hidup seseorang akan semakin tinggi. Dengan demikian individu tersebut akan melakukan berbagai cara untuk mendapatkan imbalan yang lebih dan semakin lebih tinggi lagi.

Berdasarkan hasil analisis regresi linier berganda pada Uji $t$ terhadap hipotesis ketiga $\left(\mathrm{H}_{3}\right)$ dapat dilihat bahwa sistem pengendalian internal tidak berpengaruh terhadap fraud pengadaan barang/jasa pada instansi pemerintah desa di kabupaten lombok tengah. Hal ini dapat dilihat dari taraf signifikansinya yaitu sebesar 0,364 lebih besar dari 0,05 dan Uji t menunjukkan nilai 0,911 yang berarti lebih kecil dari t tabel 1,972 maka $\mathrm{H}_{3}$ ditolak.

Penyebab terjadinya kelemahan sistem pengendalian internal bisa disebabkan oleh pejabat yang bertanggungjawab lalai dan belum optimal dalam melaksanakan tugas dan tanggungjawab mereka. penelitian ini sejalan dengan penelitian Akbar, et al., (2012) dimana sistem pengendalian internal sudah berjalan dengan baik dan selayaknya, akan tetapi masih terdapat salah saji atau salah material yang ditimbulkan karena moral seseorang individu untuk berbuat curang dan seakan sistem yang berjalan salah. Penelitian lain yang sejalan juga ditunjukkan oleh Rahmi \& Helmayunita, (2019) menunjukkan bahwa sistem pengendalian internal tidak berpengaruh pada kecenderungan kecurangan akuntansi. Hal ini membuktikan lemahnya sistem pengendalian internal khususnya lingkungan pengendalian dan monitoring.

Hasil penelitian ini mendukung teori fraud triangle yaitu kesempatan/peluang (Preceive Opportunity). Kesempatan/peluang (Preceive Opportunity) adalah peluang terjadinya fraud akibat lemahnya atau tidak efektifnya kontrol sehingga membuat peluang terjadinya fraud. Dimana semakin baik sistem pengendalian internal suatu instansi maka akan mengurangi tingkat kecurangan (fraud) sebaliknya semakin lemah sistem pengendalian internal suatu instansi maka tindakan kecurangan ( fraud) juga akan semakin meningkat.

Budaya etis organisasi merupakan satu pola tingkah laku, kepercayaan yang telah menjadi suatu panutan bagi semua anggota organisasi, tingkah laku disini merupakan suatu tingkah laku yang dapat diterima oleh moral dan benar secara hukum (Panggabean 2016). Suatu budaya etis organisasi yang buruk akan mempengaruhi seseorang dalam melakukan tindak kecurangan dan sebaliknya, apabila budaya etis organisasi tersebut semakin baik, maka akan semakin rendah tingkat terjadinya fraud.

Berdasarkan hasil analisis regresi linier berganda pada Uji t terhadap hipotesis keempat $\left(\mathrm{H}_{4}\right)$ dapat dilihat bahwa kesesuaian kompensasi berpengaruh 
terhadap fraud pengadaan barang/jasa pada instansi pemerintah desa di kabupaten lombok tengah dengan melihat taraf signifikansinya yaitu sebesar 0,042 kurang dari 0,05 dan Uji t menunjukkan nilai 2,052 yang berarti lebih besar dari $t$ tabel 1,972. Hubungan yang ditunjukkan oleh koefisien regresi adalah negatif, artinya semakin tinggi tingkat budaya etis orgaisasi maka fraud pengadaan barang/jasa akan semakin meurun, sehingga $\mathrm{H}_{4}$ diterima.

Hasil penelitian tersebut sejalan dengan penelitian yang dilakukan oleh Aji (2013) menunjukkan bahwa etika pengadaan berpengaruh negatif dan signifikan terhadap penyimpangan dalam pengadaan barang dan jasa pemerintah. Penelitian Panggabean (2016) menunjukkan bahwa secara serempak budaya etis organisasi berpengaruh signifikan terhadap fraud di lingkungan pemerintah, namun secara parsial budaya etis organisasi berpengaruh negatif signifikan terhadap fraud di lingkungan instansi pemerintah. Penelitian ini sejalan dengan teori fraud triangle yaitu rasionalisasi (rationalization). Rasionalisasi (Rationalization) adalah fraud terjadi karena kondisi nilai-nilai etika lokal yang mendorong/membolehkan terjadinya fraud. Budaya etis organisasi yang buruk akan mempengaruhi seseorang dalam melakukan tindak kecurangan dan sebaliknya, apabila budaya etis organisasi tersebut semakin baik, maka akan semakin rendah tingkat terjadinya fraud.

\section{SIMPULAN}

Berdasarkan hasil analisa yang telah dilakukan pada 140 Tim Pengelola Kegiatan (TPK) pada Instansi Pemerintah Desa di Kabupaen Lombok Tengah, maka dapat disimpulkan bahwa: variabel Karakteristik Tim Pengelola Kegiatan (TPK) (X1) berpengaruh negatif signifikan terhadap fraud pengadaan barang/jasa, maka $\mathrm{H}_{1}$ diterima. Artinya semakin baik karakteristik Tim Pengelola Kegiatan (TPK) maka dapat menurunkan potensi terjadinya fraud. Sedangkan variabel Kesesuaian Kompensasi (X2) berpengaruh positif signifikan terhadap fraud pengadaan barang/jasa, maka $\mathrm{H}_{2}$ ditolak. Artinya jika kesesuaian kompensasi tinggi maka fraud pengadaan barang/jasa juga tinggi. Selain itu, variabel Sistem Pengendalian Internal (X3) tidak berpengaruh terhadap fraud pengadaan barang/jasa, maka variabel X3 ditolak. Hal ini menunjukkan bahwa lemahnya sistem pengendalian internal khususnya lingkungan pengendalian dan monitoring. Sedangkan, variabel Budaya Etis Organisasi (X4) berpengaruh negatif signifikan terhadap fraud pengadaan barang/jasa, maka variabel X4 diterima. Hal ini menunjukkan bahwa semakin tinggi tingkat budaya etis organisasi dalam suatu instansi maka akan megurangi adanya tindakan kecurangan (fraud).

Berdasarkan evaluasi atas hasil penelitian dan keterbatasan yang ada dalam penelitian ini, beberapa saran yang diharapkan untuk peneliti selanjutnya, antara lain : 1) Penelitian selanjutnya disarankan untuk menambah jumlah sampel dari kalangan aparaturpemerintah desa tidak hanya panitia pengadaan barang/jasa saja, sehingga hasil penelitian dapat digeneralisasikan sesuai dengan kondisi yang terjadi di desa. 2) Penelitian selanjutnya disarankan untuk melakukan wawancara dan dapat memasukkan masyarakat desa sebagai sampel penelitian sehingga dapat diperoleh hasil penelitian yang dapat menjelaskan pengaruh keecurangan (Fraud) pengadaan barang/jasa di desa secara kuat. 3) 
Variabel independen perlu ditambah seperti kontrol atasan, etika atasan, ketaatan aturan akuntansi, komitmen organisasi, sehingga dapat diperoleh hasil penelitian yang dapat menjelaskan pengaruh terjadinya kecurangan (fraud) pengadaan barang/jasa di desa secara kuat.

\section{REFERENSI}

Ahriati, D., Basuki, P., \& Widiastuty, E. (2015). Analisis Pengaruh Sistem Pengendalian Internal, Asimetri Informasi, Perilaku Tidak Etis Dan Kesesuaian Kompensasi Terhadap Kecenderungan Kecurangan Akuntansi Pada Pemerintah Daerah Kabupaten Lombok Timur. Jurnal InFestasi.

Arifianti, R., Santoso, B., \& Handajani, L. (2016). Perspektif Triangle Fraud Theory Dalam Pengadaan Barang/Jasa Di Pemerintah Provinsi NTB. InFestasi. https://doi.org/10.21107/infestasi.v11i2.1132

Clinard, M. B., \& Cressey, D. R. (1954). Other People's Money: A Study in the Social Psychology of Embezzlement. American Sociological Review. https://doi.org/10.2307/2087778

Handoko, H. (2010). Manajemen Personalia Sumber Daya Manusia, Edisi Kedua. In BPFE UGM Persada. https://doi.org/10.4324/9780203488430

Heljapri. (2015). Perbedaan Persepsi Antara Pihak Internal Instansi Pemerintahan Dengan Auditor BPKP Tentang Aspek Penyebab Fraud Pengadaan Barang dan Jasa Pada Lingkungan Pemerintah Propinsi Sumatera Barat. Jurnal Akuntansi.

Jensen, M. C., \& Meckling, W. H. (1976). Theory of the firm: Managerial behavior, agency costs and ownership structure. Journal of Financial Economics. https://doi.org/10.1016/0304-405X(76)90026-X

Mardiasmo. (2018). Perpajakan Edisi Terbaru 2018. In Penerbit ANDI.

Najahningrum, A. F. (2013). Faktor-Faktor Yang Mempengaruhi Kecenderungan Kecurangan (Fraud) : Persepsi Pegawai Dinas Provinsi DIY. Lib.Unes.Ac.Id.

Nisa Nurharjanti, N. (2017). Faktor-Faktor yang Berhubungan dengan Fraud Pengadaan Barang/Jasa di Lembaga Publik. Jurnal Akuntansi Dan Investasi. https://doi.org/10.18196/jai.180284

Rahmi, N. ., \& Helmayunita, N. (2019). Pengaruh Pengendalian Internal, Kesesuaian Kompensasi, dan Moralitas Individu terhadap Kecenderungan Kecurangan Akuntansi. Jurnal Eksplorasi Akuntansi.

Sanuari, N. (2014). pengaruh sistem pengendalian internal, kesesuaian kompensasi, dan moralitas manajemen terhadap kecenderungan kecurangan akuntansi (studi empiris pada Kantor BUMN Kota Padang). EJournal Akuntansi Universitas Negeri Padang.

Shintadevi, P. F. (2016). Pengaruh Keefektifan Pengendalian Internal, Ketaatan Aturan Akuntansi Dan Kesesuaian Kompensasi Terhadap Kecenderungan Kecurangan Akuntansi Dengan Perilaku Tidak Etis Sebagai Variabel Intervening. Nominal, Barometer Riset Akuntansi Dan Manajemen. https://doi.org/10.21831/nominal.v4i2.8003

Skinner, J., \& Ferrell, O. C. (2010). Ethical Behavior and Bureaucratic Structure in Marketing Research Organizations Author(s): 25(1), 103-109.

Sugiyono. (2015). Metode Penelitian. Metode Penelitian.

Tuanakotta, T. M. (2010). Akuntansi Forensik \& Audit Investigatif. In Edisi 4. 
https://doi.org/10.1016/j.clay.2015.06.031

Wexley, Kenneth, N dan Yukl, G. (2000). Perilaku Organisasi dan Psikologi Personalia, terjemahan Muh Shobaruddin. Rineka Cipta, Jakarta. https://doi.org/10.15294/jejak.v7i1.3596

Zulaikha, Z., \& Hadiprajitno, P. T. B. (2016). Faktor-Faktor Yang Memengaruhi Procurement Fraud: Sebuah Kajian Dari Perspektif Persepsian Auditor Eksternal. Jurnal Akuntansi Dan Keuangan Indonesia. https://doi.org/10.21002/jaki.2016.11

https://www.gatra.com/detail/news/371911-Penggunaan-Dana-Desa-di-NTBTanpa Pertanggungjawaban-Menteri-Eko:-Akan-Dikirim-Tim-Satgas (diakses pada 24 Juli 2019). 